\title{
Investigation of uranium sorption from acidic sulfate solution using organosilicate compound and Amberlite IRA 402
}

\author{
Mohamed Nouh Kouraim *, Mohamed El Said Sheta and Mostafa Mahmoud Abd Elaal \\ Nuclear Materials Authority, El Maadi, 530, Egypt \\ *Corresponding author at: Nuclear Materials Authority, El Maadi, 530, Egypt. \\ Tel.: +2.0122.5157622. Fax: +2.02.7585822. E-mail address: nouhnma2@yahoo.com (M.N. Kouraim).
}

\section{ARTICLE INFORMATION}

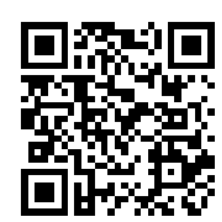

DOI: $10.5155 /$ eurjchem.5.3.446-450.1026

Received: 31 January 2014

Received in revised form: 01 March 2014

Accepted: 02 March 2014

Online: 30 September 2014

\section{KEYWORDS}

Sorption

Uranium

Investigation

Sulfate solution

Amberlite IRA 402

Organosilicate compound

\section{Introduction}

Uranium is widely distributed in different rocks, especially in igneous rocks and some sedimentary rocks of high organic content [1]. One of the best known and widely used processes in production of uranium is that based on its leaching by sulfuric acid from its ores. In the uranium leaching by sulfuric acid, the leach liquor containing neutral $\left[\mathrm{UO}_{2} \mathrm{SO}_{4}\right]^{0}$, anionic $\left[\mathrm{UO}_{2}\left(\mathrm{SO}_{4}\right)_{2}\right]^{-2}$ and $\left[\mathrm{UO}_{2}\left(\mathrm{SO}_{4}\right)_{3}\right]^{-4}$ complexes. The presence of these complexes depends on the amount of free sulfuric acid and sulfate anions in the leaching solution [2]. This process followed by recovery of uranium from sulfate leach liquor based on the capability of anionic sorbents to quantitatively sorb uranium in the form of negatively charged complexes, mainly, $\left.\left[\mathrm{UO}_{2} \mathrm{SSO}_{4}\right)_{3}\right]^{4-}$ [3]. In this process, the majority of other elements remain in solution. The sorption of uranium from sulfuric acid leaching liquors using anionic sorbents can be described by reactions of complexation and ion exchange $[4,5]$.

$\left(\mathrm{R}^{+}\right) \mathrm{X}^{-}+\left[\mathrm{UO}_{2} \mathrm{SO}_{4}\right]^{0} \leftrightharpoons\left(\mathrm{R}^{+} \mathrm{X}^{-}\right)\left[\mathrm{UO}_{2}\left(\mathrm{SO}_{4}\right)_{2}\right]^{0}$

$\mathrm{n}\left(\mathrm{R}^{+}\right) \mathrm{X}^{-}+\left[\mathrm{UO}_{2}\left(\mathrm{SO}_{4}\right)_{2}\right]^{2-} \leftrightharpoons\left(\mathrm{R}^{+}\right)_{\mathrm{n}}\left[\mathrm{UO}_{2}\left(\mathrm{SO}_{4}\right)_{2}\right]^{0}+\mathrm{nX}^{-}$

$\mathrm{n}\left(\mathrm{R}^{+}\right) \mathrm{X}^{-}+\left[\mathrm{UO}_{2}\left(\mathrm{SO}_{4}\right)_{3}\right]^{4-} \leftrightharpoons\left(\mathrm{R}^{+}\right)_{n}\left[\mathrm{UO}_{2}\left(\mathrm{SO}_{4}\right)_{3}\right]^{0}+\mathrm{nX}^{-}$
The sorbents may be organic or inorganic but in surface chemistry, inorganic sorbents have a number of advantages [6] making them preferred than the organic ones. It was found that inorganic sorbents are highly resistant towards radiation damage, and have a high thermal and chemical stability. Most previous studies have been performed on the sorption of uranium by natural silicate materials [7-10], while only limited studies have been made on the sorption of uranium by synthetic silicate compounds where appropriate chelating reagents can be immobilized onto the silicate supports [11,12]. Recently, the synthesis effort was focused on the modification of ordered mesoporous silicas in order to achieve highly selective materials for the separation of different metal ions [13-15]. However other sorbents have also been applied for a selective separation of uranium but, these sorbents suffer from the lengthy period of preparation and the presence of electrolytes decrees its sorption capacity [16-19]. Accordingly we are hardly trying to find a new modified sorbents to overcome these difficulties. In this work the sorption properties was investigated for the synthetic Organosilicate compound (OSC) in regard to uranium from acidic sulfate solution under a variety of conditions with compared to Amberlite IRA 402. 


\section{Experimental}

\subsection{Reagents}

A stock solution of uranium leach liquor was prepared by leaching appropriate amounts of uranium ore (Abu Rashid Ore), $50 \mathrm{~g}$ in $250 \mathrm{~mL}(1: 5, w: v)$ sulfuric acid $(100 \mathrm{~g} / \mathrm{L})$ for 8 hours at $90^{\circ} \mathrm{C}$. Chemical composition of the leach liquor shown in Table 1. Strong anionic ion exchanger Amberlite IRA 402 in Gel form, 16-20 mesh, from Rohm and Hass Co. Arsenazo III (Fluka, Buchs, Switzerland), 0.1\% (w:v) was prepared by dissolving $0.1 \mathrm{~g}$ of the reagent in $100 \mathrm{~mL}$ of deionized water. Sodium acetate-acetic acid buffer $(\mathrm{pH}=4.5)$ was used to maintain the $\mathrm{pH}$. Other reagents (BDH-England) used were also of analytical reagent grade.

Table 1. Chemical analysis of the sulfate leach liquor.

\begin{tabular}{ll}
\hline Components & Concentration, ppm \\
\hline $\mathrm{CaO}$ & 360 \\
$\mathrm{SO}_{4}$ & $300 \times 10^{3}$ \\
$\mathrm{SiO}_{2}$ & - \\
$\mathrm{P}_{2} \mathrm{O}_{5}$ & 3.5 \\
$\mathrm{Fe}_{2} \mathrm{O}_{3}$ & 513 \\
$\mathrm{U}$ & 835 \\
$\mathrm{Na}_{2} \mathrm{O}$ & 100 \\
$\mathrm{~K}_{2} \mathrm{O}$ & 222 \\
$\mathrm{TiO}_{2}$ & 0.4 \\
$\mathrm{MnO}$ & - \\
$\mathrm{MgO}$ & 267 \\
$\mathrm{Al}_{2} \mathrm{O}_{3}$ & 2.5 \\
\hline
\end{tabular}

\subsection{Instrumentation}

Shimadzu UV-VIS-160 double beam spectrophotometer using a $1 \mathrm{~cm}$ quartz cell. The $\mathrm{pH}$ values were measured using a pH-meter (Hanna Instruments, 8519, Italy).

\subsection{Uptake experiments}

Batch sorption experiments were carried out to investigate the quantitative uptake of uranium by Amberlite IRA 402 and Organosilicate compound. The analytical variables such as $\mathrm{pH}$, time, temperature, the sorbent/volume of the solution ratio (S/L) and uranium initial concentration have been studied in detail for batch sorption experiments. Uranium was standardized and determined spectrophotometrically by Arsenazo III as reported elsewhere [20].

\subsection{Preparation of organosilicate compound}

The aminopropyl functionality of silica was converted into a multifunctional ligand by additional reaction with benzoyl isothiocyanate, which normally proceeds completely $[21,22]$. A typical procedure is: $0.2 \mathrm{~g}$ of aminopropyl silica was reacted with $0.50 \mathrm{~mL}$ of benzoyl isothiocyanate $(25 \%$ excess $)$ in presence of $0.1 \mathrm{~g}$ of humic acid and in toluene as a solvent. The resulting solid was filtered out and washed with $50 \mathrm{~mL}$ of toluene and $50 \mathrm{~mL}$ of iso-propanol and dried in the vacuum oven at $90{ }^{\circ} \mathrm{C}$ for $5 \mathrm{~h}$ (Scheme 1). The yield of chemically modified sorbent was quantitative, and its capacity was found to be $3.21 \mathrm{mmol}$ benzoyl thiourea corresponding to $10.28 \%$ of Si content.

\subsection{Sorption isotherms}

Batch sorption studies of uranium was performed at room temperature $\left(25 \pm 2{ }^{\circ} \mathrm{C}\right)$ to obtain the equilibrium isotherms. For isotherm studies, a series of $50 \mathrm{~mL}$ test tubes were used. Each test tube was filled with $20 \mathrm{~mL}$ of uranium solution of varying concentrations (0.75-2.00 g/L) and a known amount of sorbent $(1 \mathrm{~g})$ was added into each test tube and agitated for various time periods. The uranium concentration retained in the sorbent phase $(\mathrm{mg} / \mathrm{g})$ was calculated by:
$\mathrm{q}_{\mathrm{e}}=\left(\mathrm{C}_{\mathrm{i}}-\mathrm{C}_{\mathrm{e}}\right) \mathrm{V} / \mathrm{m}$

where $C_{i}$ and $C_{e}$ are the initial and equilibrium concentrations of uranium $(\mathrm{mg} / \mathrm{L})$, respectively, $\mathrm{V}$ is the volume of the aqueous solutions (L), and $\mathrm{m}$ is the weight of the sorbent used in grams. The distribution of uranium between the solid liquid interface at equilibrium has been studied by the Langmuir and Freundlich isotherm models. The Langmuir isotherm equation may be written as:

$\mathrm{C}_{e} / \mathrm{q}_{\mathrm{e}}=\left(1 / \mathrm{b} . \mathrm{q}_{\mathrm{o}}\right)+\left(\mathrm{C}_{\mathrm{e}} / \mathrm{q}_{\mathrm{o}}\right)$

where $\mathrm{q}_{\mathrm{e}}$ is the amount of solute sorbed per unit weight of adsorbent $(\mathrm{mg} / \mathrm{g}), \mathrm{C}_{\mathrm{e}}$ is the equilibrium concentration of the solute in the bulk solution $(\mathrm{mg} / \mathrm{L}), \mathrm{q}_{0}$ is the monolayer adsorption capacity $\left(\mathrm{mg} \mathrm{g}^{-1}\right)$ and $\mathrm{b}$ is the constant related to the free energy of adsorption.

The Freundlich equation may be written as:

$\log q_{e}=\log K_{f}+1 / n \log C_{e}$

where $\mathrm{K}_{\mathrm{f}}$ is the constant indicative of the relative adsorption capacity of the adsorbent $(\mathrm{mg} / \mathrm{g})$ and $1 / \mathrm{n}$ is the constant indicative of the intensity of the adsorption.

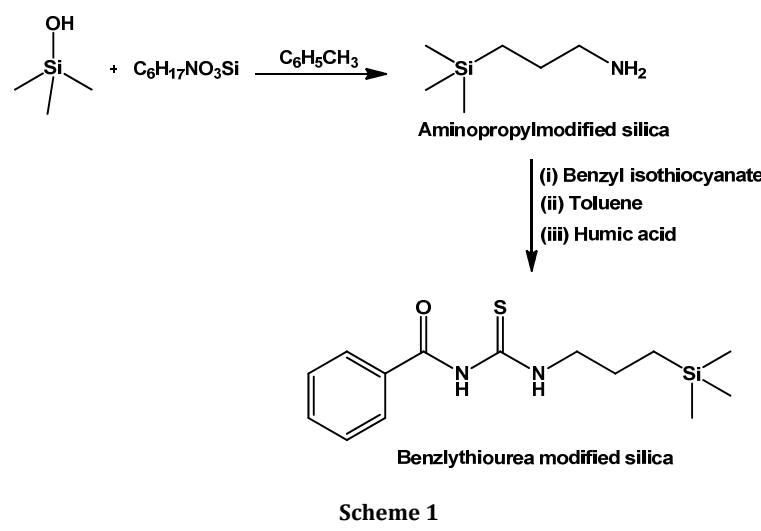

\subsection{Thermodynamics data}

The measured distribution constant $\left(K_{\mathrm{d}}\right)$ values for uranium ions sorbed from sulfuric acid solutions by Organosilicate compound and Amberlite IRA 402 can be assumed to be proportional to the corresponding equilibrium constant values. So, the Van't Hoff equation, in the form given below, can be utilized to calculate the enthalpy changes associated with the sorption of uranium ions:

$\log K_{\mathrm{d}}=\left(\Delta \mathrm{S}^{\circ} / 2.303 . \mathrm{R}\right)-\left(\Delta H^{\circ} / 2.303 . \mathrm{R} . \mathrm{T}\right)$

where $\mathrm{R}$ is the universal gas constant. The plots of $\log K_{\mathrm{d}} v s .1 / \mathrm{T}$ for the uranium sorption gives a straight line with slope equal $\Delta H^{\circ} / 2.303 . \mathrm{R}$ and intercept equal $\Delta S^{\circ} / 2.303$.R. On the other hand, the free energy for the specific sorption $\left(\Delta G^{\circ}\right)$ was calculated from the following relation:

$\Delta G^{\circ}=\Delta H^{\circ}-\mathrm{T} \Delta S^{\circ}$

\section{Results and discussion}

\subsection{Effect of $\mathrm{pH}$ on the uptake of uranium}

Hence, the $\mathrm{pH}$ of the leach liquor influences the uranium complex and surface uranium binding sites, the effect of $\mathrm{pH}$ on uranium uptake by Organosilicate compound and Amberlite IRA 402 were studied in the range of 0.5 to 2.5 while keeping all other parameters constant as shown in Figure 1. The 
uranium uptake increases by increasing of $\mathrm{pH}$, below 0.5 , a small value of uranium uptake was recorded for Amberlite IRA 402 while a high value of uptake was found in the case of Organosilicate compound. The specific $\mathrm{pH}$ dependent trend of the uranium sorption can be explained by the ion-exchange mechanism between solution and the sorbent according to this equation:

$2(\mathrm{X}) \mathrm{H}+\mathrm{UO}_{2}{ }^{2+} \leftrightharpoons(\mathrm{X})_{2} \mathrm{UO}_{2}+2 \mathrm{H}^{+}$

where $\mathrm{X}$ represents the functional group. The small uranium uptake recorded for Amberlite IRA 402 at $\mathrm{pH}$ less than 0.5 suggested that the equilibrium is shifted to the left and the active sites become protonated and their ability for interaction with uranium ions decreases [23-25]. However, the silicates in OSC cause the occurrence of two major types of sorption sites [26]: on the basal surfaces and side faces of particles. In the former case, uranium form outer-sphere complexes by the ionexchange mechanism, and in the latter case, stable innersphere complexes are formed as a result of dissociation of Si$\mathrm{OH}$ bonds localized on side faces. At low $\mathrm{pH}$, when the dissociation of $\mathrm{Si}-\mathrm{OH}$ bonds is suppressed, the uptake of uranium is low but remains higher than Amberlite IRA 402 due to the presence of humic acid in OSC which assumed to behave as a penetrable gel-like structure toward uranium ions even when they are free in solution. Humic acid (HA) has a macromolecular structure and is assumed that only a small fraction of the "sorbed" carboxylic and phenolic groups directly interact with the silica surface sites, while the remaining "sorbed" groups are free to interact with uranium ions in the solutions [27]. Therefore, the species of uranium sorbed on the surface of $\mathrm{HA}-\mathrm{SiO}_{2}$ sorbents may be presented as $\mathrm{SiO}_{2}-\mathrm{HA}-\mathrm{U}$ or $\mathrm{HA}-\mathrm{SiO}_{2}-\mathrm{U}[28]$.

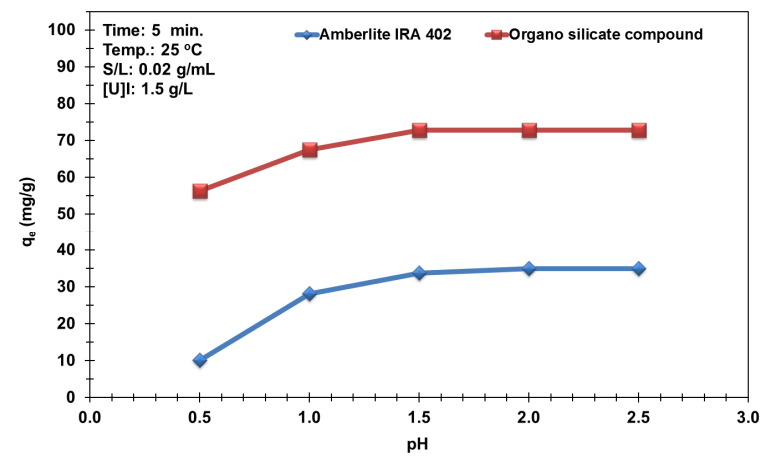

Figure 1. Effect of $\mathrm{pH}$ on the uranium uptake.

\subsection{Effect of contact time}

For the evaluation of uranium uptake as a function of contact time, from 1 to 60 minutes contact intervals were applied for both sorbents, Organosilicate compound and Amberlite IRA 402. The results of uranium uptake are shown in Figure 2, clearly, a rapid uranium uptake was noticed within the initial 5 min. Almost $90 \%$ of the maximum uptake of either Organosilicate compound or Amberlite IRA 402 was reached within 10 min while the maximum uptake was reached after 20 min. The rapid uptake process may indicate that most of the active sites of the sorbents are exposed for interaction with uranium ions. Organosilicate compound showed higher sorption for uranium compared to Amberlite IRA 402 which may be attributed to the good chelating power of organosilicate compound which achieves better coordination with uranium ions due to its compactness.

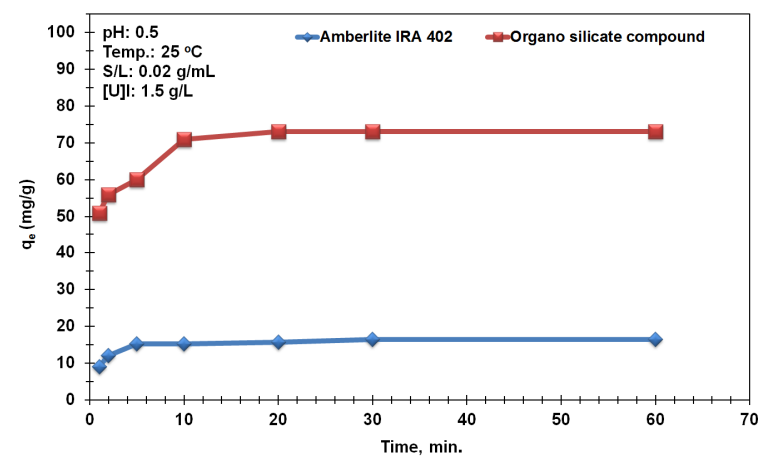

Figure 2. Effect of time on the uranium uptake.

\subsection{Effect of temperature and thermodynamics}

The effect of temperature variation from $30-75{ }^{\circ} \mathrm{C}$ was examined on the uptake of uranium by Organosilicate compound and Amberlite IRA 402 sorbents as shown in Figure 3 . The uptake decreased with an increase of the temperature. The plots of $\log K_{\mathrm{d}} v s .1 / \mathrm{T}$ for the uranium uptake are shown in Figure 4 . The estimated thermodynamic values are given in Table 2.

Table 2. Thermodynamic data of uranium sorption.

\begin{tabular}{llll}
\hline Sorbents & \multicolumn{3}{l}{ Thermodynamics data } \\
\cline { 2 - 4 } & $\boldsymbol{\Delta} \boldsymbol{H}^{\circ}$ & $\boldsymbol{\Delta} \boldsymbol{S}^{\circ}$ & $\boldsymbol{\Delta} \boldsymbol{G}^{\circ}$ \\
\hline Organosilicate compound & -35 & -570 & 169 \\
Amberlite IRA 402 & -10 & -6.00 & 2.00 \\
\hline
\end{tabular}

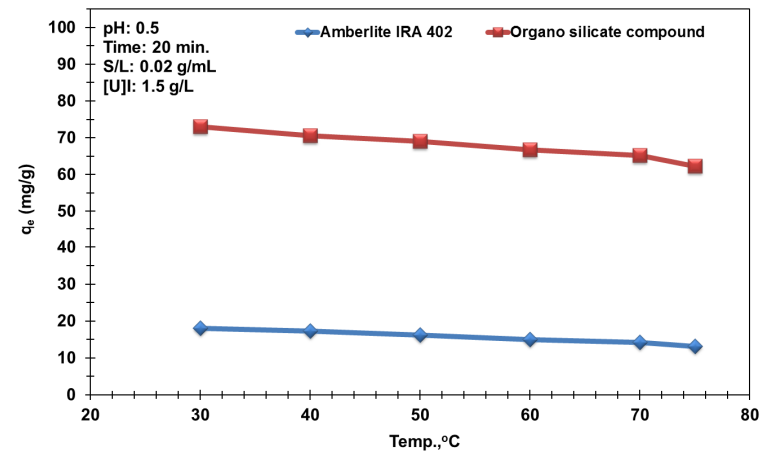

Figure 3. Effect of temperature on the uranium uptake.

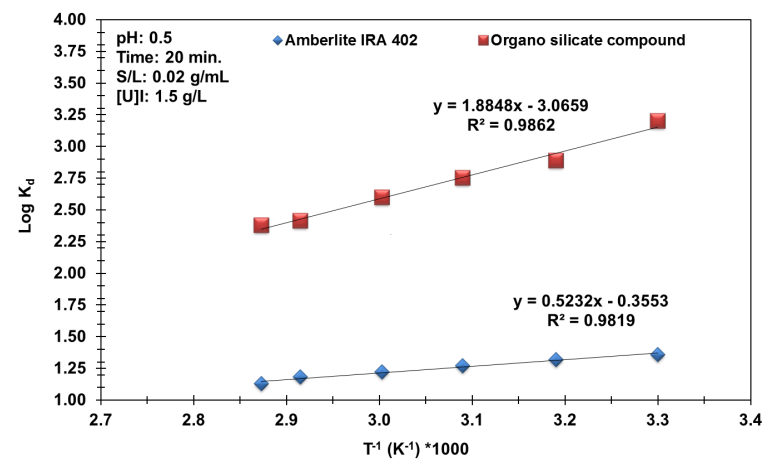

Figure 4. Thermodynamics of the uranium uptake.

The magnitude and sign of the enthalpy change $(\Delta H)$ associated with the sorption process will consist of (i) Enthalpy change for dehydration $\left(\Delta H_{\mathrm{d}}\right)$ which can be expected to be positive because energy is required to break the ion-water and 
water-water bonding of the hydrated uranium ions, and (ii) Enthalpy change for complexing $\left(\Delta H_{c}\right)$ which will make $\Delta H$ more negative due to the formation of uranium complex [29].

The negative $\Delta H$ value obtained for the uranium sorption indicates that complexation seems to be more significant than dehydration in both sorbents [30]. The low values of the enthalpy change for uranium sorption into Organosilicate compound and Amberlite IRA 402, indicates that the uranium concentration in the sorbent phase will remain constant over a temperature range for a given aqueous concentration. The positive values of $\Delta G$ indicate non spontaneous nature of uranium sorption. The increasing in the value of the entropy term due to the sorption processes involves the liberation of water molecules of hydration [31].

\subsection{Effect of solid to liquid ratio $(S / L)$}

The effect of solid mass of the sorbent/volume of the solution ratio $(\mathrm{S} / \mathrm{L})$ on the uptake of uranium was checked for Organosilicate compound and Amberlite IRA 402. The volume of solution $(20 \mathrm{~mL})$ was kept constant. As shown in Figure 5, the effect of the amount of sorbent on uranium uptake shows similarity for both sorbents. The amount of uranium sorbed from the solution increased slightly as the amount of the sorbent increased.

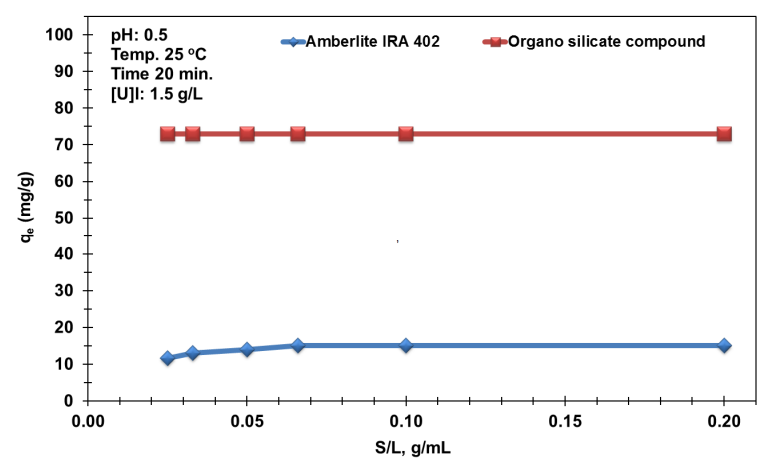

Figure 5. Effect of S/L on the uranium uptake.

\subsection{Effect of uranium initial concentration and sorption isotherm}

The uptake of uranium by Organosilicate compound and Amberlite IRA 402 sorbents were shown in Figure 6, as a function of the initial uranium concentration in the range of $0.25-2.00 \mathrm{~g} / \mathrm{L}$ at $25^{\circ}$. The uranium uptake for both sorbents was increased with increasing uranium concentration in the solution. Also the plotting of the distribution coefficient log $K \mathrm{~d}$ $v s$. the logarithm of uranium concentration gives a straight line as shown in Figure 7 with slope equal to the number of uranium molecules bonded with sorbent active site. The data show that every three active site of OSC react with one molecule of uranium where the same number of molecules required about two active site only in case of Amberlite IRA 402. The uptake data was subjected to analysis according to the Langmuir isotherm by plotting $\mathrm{C}_{\mathrm{e}} / \mathrm{q}_{\mathrm{e}} v s . \mathrm{C}_{\mathrm{e}}$ as shown in Figure 8 which gives a straight line with intercept and slope values equal to $1 / \mathrm{b} . q_{\circ}$ and $1 / q_{o}$, respectively. Also Freundlich isotherm was applied from the uptake data by plotting log qe vs. $\log \mathrm{C}_{\mathrm{e}}$ giving a straight line with slope and intercept values equal to $1 / \mathrm{n}$ and $\log \mathrm{K}_{\mathrm{f}}$, respectively as shown in Figure 9. The isotherm data for the uranium sorption by Organosilicate compound and Amberlite IRA 402 were calculated from the slopes and intercepts of Figures 8 and 9 and reported in Table 3.

The values of $b$ for Organosilicate compound are higher than that for Amberlite IRA 402. Higher b values refer to strong interaction between uranium and the active sites of the sorbent [32].

Table 3. Isotherm data of uranium sorption.

\begin{tabular}{|c|c|c|c|c|}
\hline \multirow[t]{3}{*}{ Sorbents } & \multicolumn{4}{|c|}{ Isotherm data } \\
\hline & \multicolumn{2}{|c|}{ Langmuir } & \multicolumn{2}{|c|}{ Freundlich } \\
\hline & $q_{o}(\mathrm{mg} / \mathrm{g})$ & b & $1 / n$ & $\log K_{\mathrm{f}}$ \\
\hline Organosilicate compound & 80 & 0.025 & 0.24 & 1.20 \\
\hline Amberlite IRA 402 & 20 & 0.003 & 0.29 & 0.29 \\
\hline
\end{tabular}

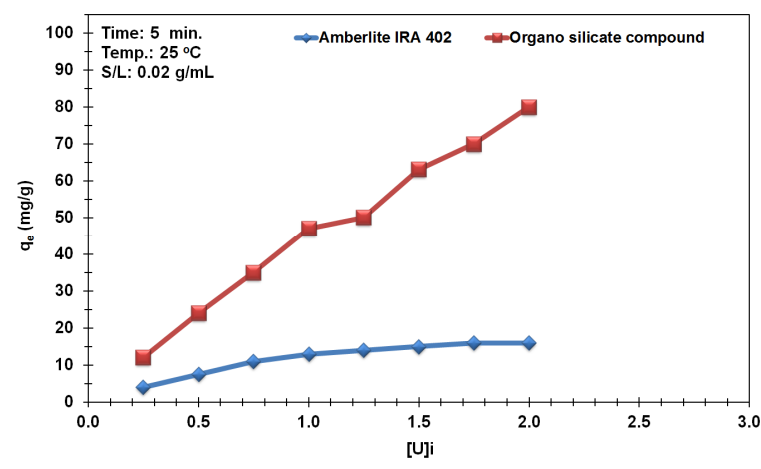

Figure 6. Effect of uranium initial concentration on the uranium uptake.

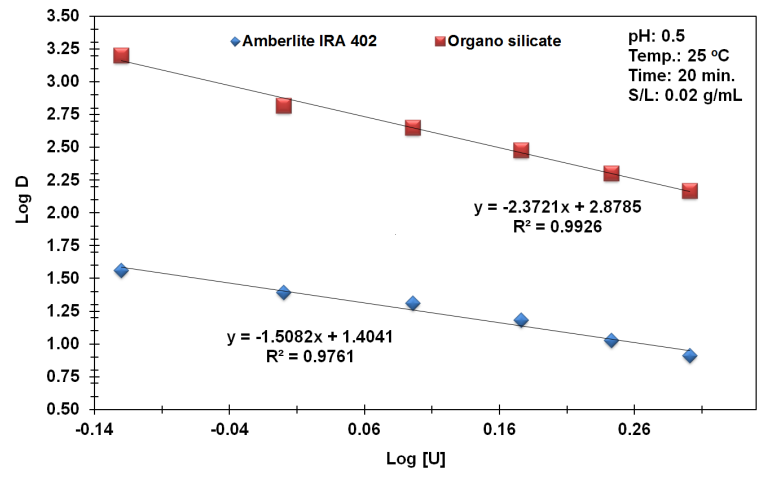

Figure 7. $\log \mathrm{D} v s . \log \mathrm{U}$.

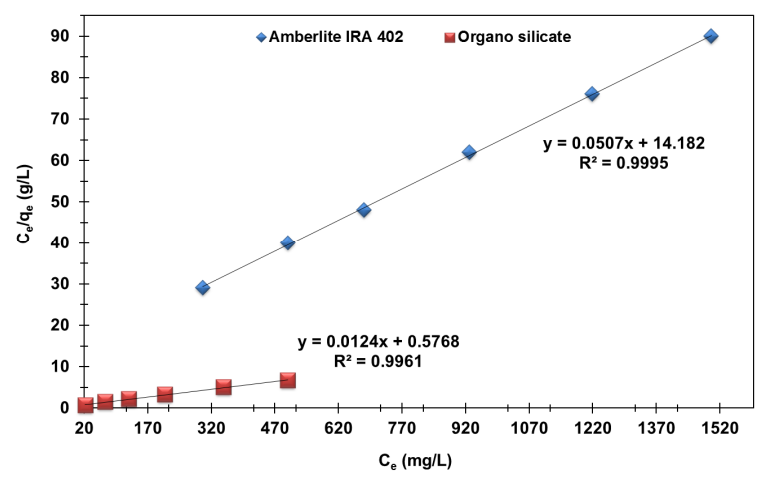

Figure 8. Langmuir isotherm of the uranium uptake.

\subsection{Uranium elution from Organosilicate compound and Amberlite IRA 402}

Different eluents used for uranium desorption from Organosilicate and Amberlite IRA 402 was investigated as shown in Figure 10. It was found that $\mathrm{KNO}_{3}$ is the most effective one for uranium desorption even at low concentration reached 1 molar. 


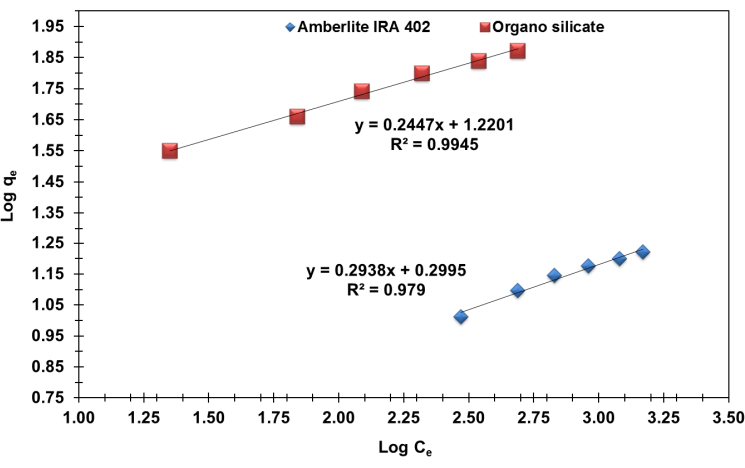

Figure 9. Freundlich isotherm of the uranium uptake.

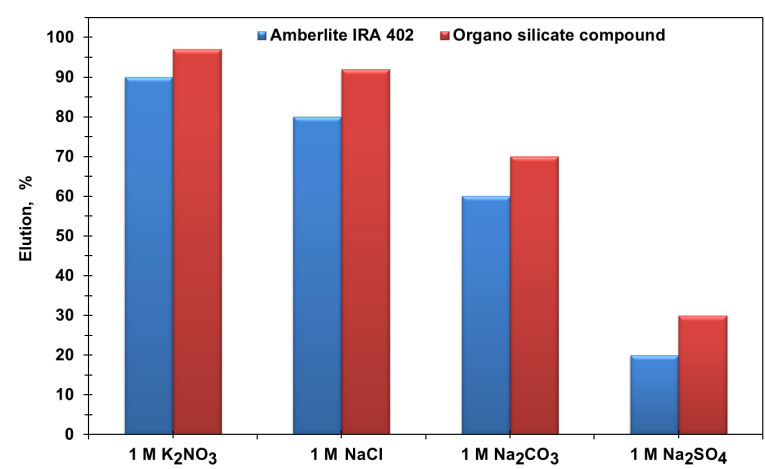

Figure 10. Effect of the different eluents on the uranium elution.

\section{Conclusions}

Chemically synthesized Organosilicate compound were tested against the Amberlite IRA 402 toward the sorption of uranium from its sulfate leach liquor. Organosilicate compound showed higher uranium sorption affinity with respect to Amberlite IRA 402. The developed Organosilicate compound was successful as a good sorbent for the uptake of uranium from highly acidic sulfate leach liquor. The most highlighting features of the sorbent are its uranium sorption capacity with good enrichment factor values and enhanced sorption rate due to the good hydrophilic character. Also, the developed sorbent is highly durable under acidic conditions which is reflected from its greater reusability nature. The interaction of uranium ions with the active sites of the studied Organosilicate compound found to be higher than that of Amberlite IRA 402. The sorbents obtained were regenerated using $\mathrm{KNO}_{3}$

\section{References}

[1]. Eisenbud, M. Environmental Radioactivity from Natural, Industrial, and Military Sources, Academic Press, San Diego, 1987.

[2]. Zefirov, A. P.; Nevskii, B. V.; Bakhurov, V. G. In Proc. Iv Int. Conf. on The Peaceful Use of Atomic Energy, Geneva: Un Iaea, 1972.

[3]. Pakholkov, V. S.; Dreipa, E. F. Radiokhimiya 1980, 22, 534-354.

[4]. Beletskii, I. V.; Bogatkov, L. K.; Volkov, N. I. Handbook on Uranium, Skorovarov, D. I. Ed., Moscow: Energoatomizdat, 1997.

[5]. Kolomiets, D. N.; Troshkina, I. D.; Sheremetev, M. F.; Konopleva, L. V. Russ. J. Appl. Chem. 2005, 78, 722-726.

[6]. Dyer, A.; Pillinger, M. In Advance in Ion Exchange for Industry and Research, Williams, P. A.; Dyer, A. (Eds), Royal Society of Chemistry, Cambridge, 1999

[7]. Andreeva, N. R.; Chernyavskaya, N. B. Radiokhimiya 1982, 24, 9-13.

[8]. Ames, L. L.; Cgarrah, J. E.; Walker, B. A. Clays Clay Miner. 1983, 31, 321-326.

[9]. Godelitsas, A.; Misaelides, P.; Filippidis, A.; Charistos, D; Anousis, I. Sci. Total Enivron. 1995, 237, 173-174.

[10]. Godeltsas, A.; Misaelides, P.; Fllippidis, A.; Charistos, D.; Anousis, I. J. Radioanal. Nucl. Ch. 1996, 208, 393-402.

[11]. Garg, B. S.; Sharma, R. K.; Bhojak, N.; Mittal, S. Microchem. J. 1999, 61, 94-114.
[12]. Adel, M. E.; Khalifa, M. E. J. Radioanal. Nucl. Ch. 2006, 268, 341-348.

[13]. Hassan, H. H.; Mayssam, M. C.; Bassem, E.; Younes, H. Eur. J. Chem. 2013, 4, 425-433.

[14]. Feng, X.; Fryxell, G. E.; Wang, L. Q.; Kim, A. Y.; Liu, J.; Kemner, K. Science 1997, 276, 923-926.

[15]. Mercier, L.; Pinnavaia, T. Adv. Mater. 2000, 9, 500-503.

[16]. Das, N.; Das, J. Inds. J. Chem. 1989, 28, 150-156.

[17]. Philips, R.; Fritz, J. S. Anal. Chim. Acta. 1982, 139, 237-255.

[18]. Lee, C. H.; Suh, M. Y.; Kim, J. S.; Kim, D. Y.; Kim, W. H.; Eom, T. Y. Anal. Chim. Acta 1999, 382, 199-203.

[19]. Khalifa, M. E. Separ. Sci. Technol. 1998, 33, 21-23.

[20]. Marczinko, Z. Spectrophotometric Determination of Elements, John Wiley and Sons Inc., New York, USA, 1986.

[21]. Katritzky, A. R.; Meth-Cohn, O.; Rees C. W. Comprehensive Organic Functional Group Transformation, Pergamon: Oxford, 1995.

[22]. Merdivan, M.; Seyhan, S.; Gok, C. Microchim. Acta 2006, 154, 109-114.

[23]. Atia, A. A. Hydrometallurgy 2005, 80, 13-22.

[24]. Sakaguchi, T.; Nakajima, A. J. Chem. Technol. Biot .1987, 40, 131-149.

[25]. Aslani, M. A. A.; Ereal, M. Biol. Trace Elem. Res. 1994, 737, 43-45.

[26]. Sposito, G. The Surface Chemistry of Soils, New York: Oxford Univ. Press, 1984.

[27]. Strathmann, T. J.; Myneni, S. C. B. Environ. Sci. Technol. 2005, 39, 4027 4034.

[28]. Wang, X. K.; Rabung, T.; Geckeis, H.; Panak, P. J.; Klenze, R. Fanghaenel, T. Radiochim. Acta 2004, 92, 691-695.

[29]. Abusafa, A.; Yucel, H. Sep. Purif. Technol. 2002, 28, 103-116.

[30]. Abdel Raouf, M. W.; El-Kamash, A. M. J. Radioanal. Nucl. Ch. 2006, 267, 389-395.

[31]. Marcus, Y.; Kolarik, Z. J. Chem. Eng. Data 1973, 18, 155-163.

[32]. Boonamnuayvitaya, V.; Chaiya, C.; Tanthapanichakoon, W.; Jarudilokkul, S. Sep. Purif. Technol. 2004, 35, 11-22. 